\title{
Studies on effect of orange (Citrus sinensis) pomace powder on physical, chemical and nutritional quality attributes of cake
}

\author{
M.A. ZaKeR*, A.R. SAWATE, S.K. SADAWARTE, B.M. PATIL And R.B. KShIRSAGAR
}

Department of Food Engineering and Technology, College of Food Technology, Vasantrao Naik Marathwada Krishi Vidhyapeeth, PARBHANI (M.S.) INDIA

*Author for Correspondence

Research chronicle : Received : 04.10.2016; Revised : 14.10.2016; Accepted : 15.11.2016

\section{SUMMARY :}

Studies were conducted for incorporation of orange pomace powder in cake. The orange pomace powder was used in various proportion viz., 0, 5, 10, 15 and 20 per cent levels for incorporation in cake by replacing the maida. The orange pomace powder and maida was analyzed for the proximate composition. The cakes were prepared and were analyzed for its physical (specific volume, volume and weight), chemical (moisture, protein, fat, ash, fibre) and sensorial characteristics (appearance, colour, flavour, taste, texture). On the basis of overall sensory attributes, cakes prepared with 10 per cent of orange pomace powder were recorded higher acceptability as compared to other samples. The increase in powder concentration, the protein and fat content was decreased while the dietary fibre was increased. It was concluded that orange pomace powder and refined wheat flour can be substituted upto 10 per cent in refined wheat flour to prepare orange pomace powder without adversely affecting quality attributes.

KEY WORDS : Orange pomace powder, Sensory evaluation, Quality attributes

How to cite this paper : Zaker, M.A., Sawate, A.R., Sadawarte, S.K.,Patil, B.M. and Kshirsagar, R.B. (2016). Studies on effect of orange (Citrus sinensis) pomace powder on physical, chemical and nutritional quality attributes of cake. Internat. J. Proc. \& Post Harvest Technol., 7 (2) : 204-209. DOI: 10.15740/HAS/IJPPHT/ 7.2/204-209. 